\title{
EFFECTS OF HUMAN RESOURCE MANAGEMENT ON FINANCIAL PERFORMANCE OF BANKING SYSTEM OF THE REPUBLIC OF MOLDOVA
}

\author{
PhD in Economics, Assistant Professor Darovannaia Alla, \\ PhD in Economics, Assistant Professor Lopotenco Viorica \\ Republic of Moldova, Chișinau, Academy of Economic Studies of Moldova
}

DOI: https://doi.org/10.31435/rsglobal_ijite/30112019/6795

\section{ARTICLE INFO}

Received 24 September 2019

Accepted 13 November 2019

Published 30 November 2019

\section{KEYWORDS}

banking system, banking efficiency, banking staff efficiency, factorial analysis.

\begin{abstract}
The main objective of this study is to evaluate the efficiency of the banking system of the Republic of Moldova under the impact of the resources that influence it, focusing on human resources. The assessment of banking efficiency through financial indicators includes some indicators. Analyzing the notion of efficiency it can be seen that it is dependent on several qualitative factors, which gives it a complex character. The study of bank efficiency mainly involves a causal analysis of the factors that determine the decisions in a related risk environment. In the present paper, we intend to analyze in particular the effect of the banking staff management on bank efficiency, as it is mainly dependent on the way the bank employees' work. One of the essential factors influencing the Moldovan banking system analyzed in the present study is the efficiency of staff management.

From the analysis, it can be noticed that there is a link between the banking efficiency and the efficiency of banking staff management. Banks with better indicators of bank management efficiency also have higher banking efficiency.
\end{abstract}

Citation: Darovannaia Alla, Lopotenco Viorica. (2019) Effects of Human Resource Management on Financial Performance of Banking System of the Republic of Moldova. International Journal of Innovative Technologies in Economy. 6(26). doi: 10.31435/rsglobal_ijite/30112019/6795

Copyright: (C) 2019 Darovannaia Alla, Lopotenco Viorica. This is an open-access article distributed under the terms of the Creative Commons Attribution License (CC BY). The use, distribution or reproduction in other forums is permitted, provided the original author(s) or licensor are credited and that the original publication in this journal is cited, in accordance with accepted academic practice. No use, distribution or reproduction is permitted which does not comply with these terms.

1. Introduction. The financial system is a crucial sector of any economy whose level of development affects the business environment, investment, economic outlook and social dimensions, including poverty. Vulnerabilities in financial systems often generate financial crises, economic depression, and tax costs. The financial sectors are also crucial for monitoring and comparing time and space (between the economies of different countries).

Financial institutions in a country are the main channels of mediation between economies and investments. More advanced financial systems quantify, aggregate and negotiate all the risks associated with a transaction, and incite those who save to invest and give them compensation according to the extent of the risks involved. When they are effective, intermediaries enable the mobilization of savings from various sources to engage them in more productive uses that benefit not only investment recipients but also the economy as a whole.

By linking those who invest with those who save, banks play a crucial role in allocating resources, diversifying risks and reducing information friction on credit markets. Limited access to credit for individuals and businesses prevents investment in human and physical capital, innovation and productivity gains. In addition to long-term economic growth, empirical evidence also shows that access to finance plays a vital role in shaping economic differences between individuals.

For the Republic of Moldova, some harsh lessons have highlighted the need to understand the principal vulnerabilities of the financial system as well as possible. The degree of development of the financial system and its fundamental element - the banking system, determines to a large extent the 
real possibilities of the Moldovan economy, and the inefficiencies in the financial system can contribute to malfunctions and imbalances over time.

The contemporary banking system can be regarded as an orderly set of resources (labor, material, technical, financial, information technology) which, in interaction, constitutes a holistic formation with such new properties lacking in one supply, profitable product and quality services to customers. Each resource in its way influences the efficiency of the banking system.

From this point of view, we will analyze each of the resources that influence the banking efficiency, the primary emphasis; however, we will put it on the effectiveness of the banking staff management.

The article will be organized as follows. In the second section, there will be a review of the specialized literature on the importance of banking staff management in the context of the banking system's efficiency. The third section of the document will be devoted to describing the empirical methodology of the research. The data and variables used in the analysis will be presented in Section Four. The results of applying the method to our data and their implications will be analyzed in the fifth section. Finally, the conclusions will be presented in Section Five.

The main objective of the study is to determine the efficiency of the banking system of the Republic of Moldova under the impact of the resources that influence it, focusing on human resources.

2. Literature review. In the literature, studies on banking efficiency have become a domain determined by the empirical economy. These studies have developed a relatively standardized methodology in which efficiency determinants use a two-step approach. In the first stage, the efficiency and variation of productivity are evaluated (by financial coefficients or by parametric methods), and subsequently, these efficiency scores and productivity changes are regressed on the set of determinant variables. [1] Furthermore, as Sufian [2] mentions, the factors that influence the bank's performance are regressed on the overall efficiency of factor productivity. The primary purpose of the second phase of Tobit's regression is to determine which factors significantly influence productivity efficiency as a whole and to estimate the magnitude of the marginal effects of factors.

In the literature, some empirical studies on bank profitability can be identified, focusing on specific countries, while others have focused on a group of countries. For example, recent studies focusing on bank efficiency in countries such as Austria [3], the United States of America [4], Malaysia [5], South Africa [6] , but also groups of countries like Latin America [7] , Fertile Crescent Countries [8].

A central term in this study is 'staff efficiency,' which has a direct impact on bank efficiency. Paradoxically, but there seems to be a minimal number of studies on the relevance of staff in banking efficiency [9], [10]. Bowra and Niazi [11] found that HR practices and employee performance have a positive and significant relationship, and so it is essential for banks to understand that their HR practices affect employees' performance and in turn affect performance general of a bank.

3. Methodology and data. Analyzing the concept of efficiency can be seen that it is dependent on many qualitative factors, which gives it a complex character. The study of the efficiency of the financial system necessarily involves a causal analysis of the factors that determine the decisions in a related risk environment. Assessing the factors that influence the efficiency of the financial system is not an easy task, as some factors need to be taken into account. That is why different studies that have examined the magnitude of the financial system's efficiency have tried to highlight the variables that influence it. As a rule, in the literature, the influence factors on the financial system are divided into two categories: endogenous factors and exogenous factors.

Endogenous factors. These variables are decision variables specific to the entire financial system; in other words, they can directly or indirectly influence the technological process of the components of the financial system.

Exogenous or environmental factors. They are primarily made up of variables that describe the conditions of the environment in which the financial system develops, and those that are outside its influence and cannot be controlled by the financial system institutions. Therefore, the elements of the financial system can only, within the limits of its capacity, respond to changes in these factors and adapt to the new conditions of activity.

In such situations, the technique of factorial analysis is used in international practice because it is a method by which complex phenomena can be explained.

Factorial analysis has begun to be used in the study of human intelligence as a way of comparing the results of objective tests and of building matrices to define the correlations between these results and, at the same time, to identify common factors for these results. In a period, the 
factorial analysis was used only in the field of psychology, later being taken up in economic analyses, when it became an established statistical method. [12]

Given that factorial analysis is based on correlation analysis, the data subject to analysis will have to meet all the conditions required by the correlation analysis: values measured on a parametric scale, normal distribution (less restrictive as the sample volume is more substantial, according to the central limit theorem). Unlike other statistical techniques, in factorial analysis, as in the case of correlation, no distinction is made between dependent variables and dependent variables.

The main problem of factorial analysis is to find variables that have as much "common" variation (information) as possible, so that condensation leaves as little useful information as possible

Another classification of the factors influencing the efficiency of the banking system, which is common in the literature, is the following: bank-specific factors; industry-specific factors; macroeconomic factors. [13]

Factors specific to the bank. Some of the bank's specific factors usually include size; deposits; business mix and diversification; operating efficiency.

The size of the bank is measured by the natural logarithm of total assets in most studies. Bank deposits are valued by the ratio of total deposits to total assets. To determine the level of diversification is used the ratio of other operating income to average total assets. Operational efficiency is determined by the ratio of operational expenditure to interest income.

Factors specific to the banking industry. The assessment of the market structure of the banking sector is achieved by using the concentration ratio, which measures the proportion of total assets of a controlled industry of the three largest companies. [14]

Macroeconomic factors. Banking performance may be affected by recessions and rises in many ways. During a period of slow economic activity, bank loans are more likely to fall, and credit quality may deteriorate, increasing the risk of default. We use GDP per capita growth as a proxy for cyclical production. The second crucial macroeconomic variable is the inflation rate as measured by the percentage change in the deflator. [15]

Empirical analysis and results. The financial system of the Republic of Moldova is a bankbased one, with the banking system accounting for $88.79 \%$ of the total assets of the financial system. In this context, banks in the Republic of Moldova have a leading role in financial intermediation.

The banking sector in the Republic of Moldova is a source of growth and capitalization of the internal market, from which in general, depends to a large extent the financial stability and sustainability of the economy. The redistribution of financial flows cannot take place, thus avoiding the banking system, and therefore the efficiency of banking activity under the current conditions is one of the priority research directions in order to identify and quantify the factors of influence on the efficiency of the banking system.

The banking system can perform financial intermediation, supply banking services, and profitmaking differently.

The issue of banks' efficiency, of course, is of great importance: in fact, the exact way in which its own and borrowed funds are successfully managed and determines the success of the operation of the particular banking institution, but also the banking system as a whole.

The financial results of 2018 proved to be more favorable for Moldovan banks - net profit was 16351.14433 million MDL or 953.825496 million USD, 7\% more than in the previous year. At the same time, the main contribution to the aggregate profit of the Moldovan banking system was made by the systemic banks (B.C. "MOLDOVA - AGROINDBANK" S.A.; B.C. "MOBIASBANCA - Groupe Societe Generale" S.A.; B.C. "Moldindconbank" S.A.; B.C. "VICTORIABANK" S.A.) the profit of which constituted almost $92 \%$ of the profit of the entire banking system in 2018.

Banks in the Republic of Moldova receive revenues from three primary sources: interest (40\%), total operating income (43\%) and fees and commissions (16\%). The financial result of the bank's activity is made up of the net income for each of these business lines (revenue minus expenses), taking into account maintenance costs and additional indicators. At the same time, in 2018, net operating income exceeded profit from interest income.

In general, most studies on the assessment of banks' efficiency have focused on two methods: the financial indicators method and the econometric method.

To begin with, we will briefly analyze the financial coefficients of the Moldovan banking system. 


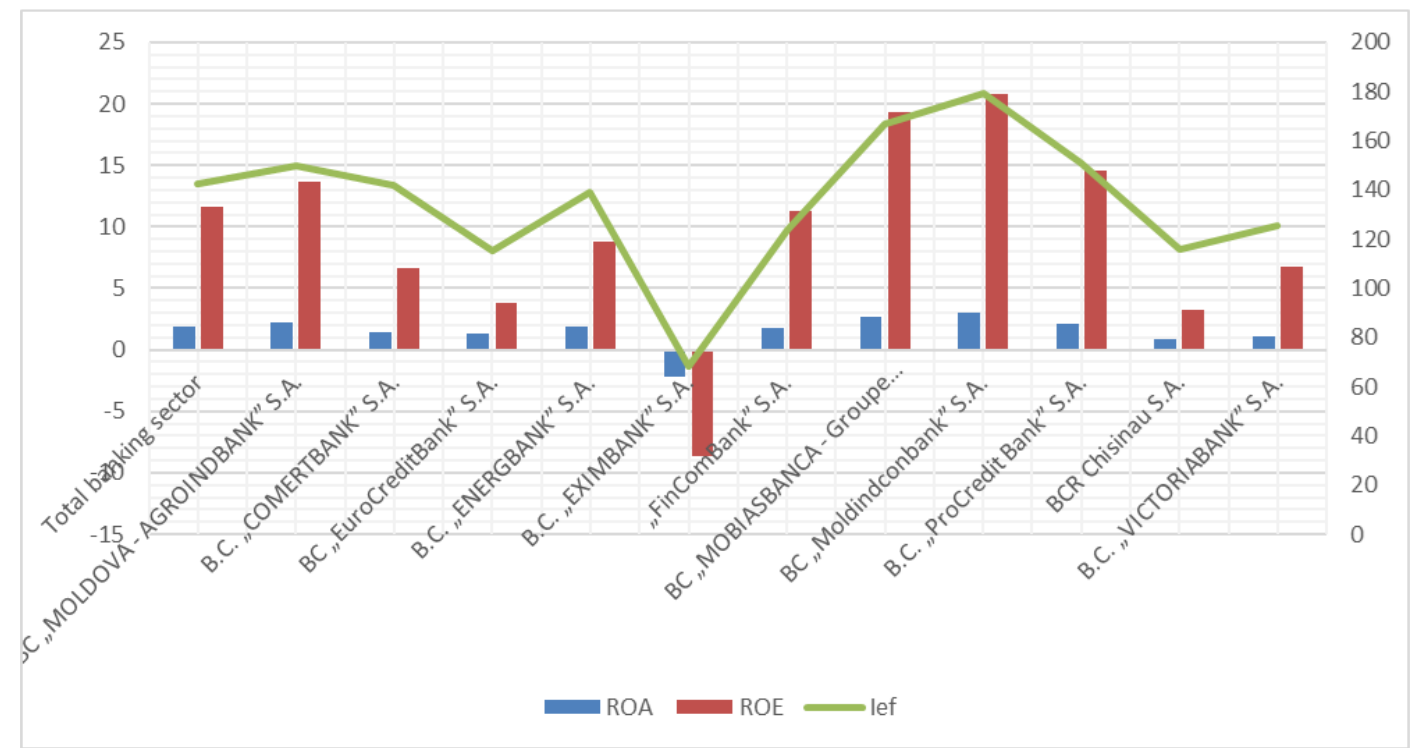

Fig.1. Commercial Banks Profitability Indicators in Republic of Moldova, (\%) [16]

The indicators of the efficiency of the banking system in the Republic of Moldova calculated based on 11 banks indicate the following ROA-1.9\%, ROE-11.6\%, Ief-142.65\% (the record of the Moldovan banking system in the efficiency was established in 2007 ( ROA-3,91\% and ROE-23,97\%)). If we analyze the effectiveness of the banks, we note that three of the four systemic banks (BC „Moldindconbank” S.A. ROA $2.96 \%$ ROE 20.81\% Ief 179.14\%;BC „MOBIASBANCA - Groupe Societe Generale” S.A. ROA $2.7 \%$ ROE 19.33\% Ief 166.74\%; BC „MOLDOVA - AGROINDBANK” S.A., ROA-2.2 \% ROE-13.63\% Ief- $149.82 \%$ ) are leaders in efficiency, at the opposite is positioned BC "EXIMBANK" S.A. with the following values: ROA $-2.17 \%$, ROE-8.7\%, Ief $68.51 \%$.

The obtained results indicated that during the studied period, there was a directly proportional relationship between the evolution of the efficiency index (vertical scale) and the ROE and ROA rates. The relatively low profitability in the Moldovan banking system was mainly due to the reduction of credit (with direct consequences on the decrease in interest income) and the tightening of supervisory requirements.

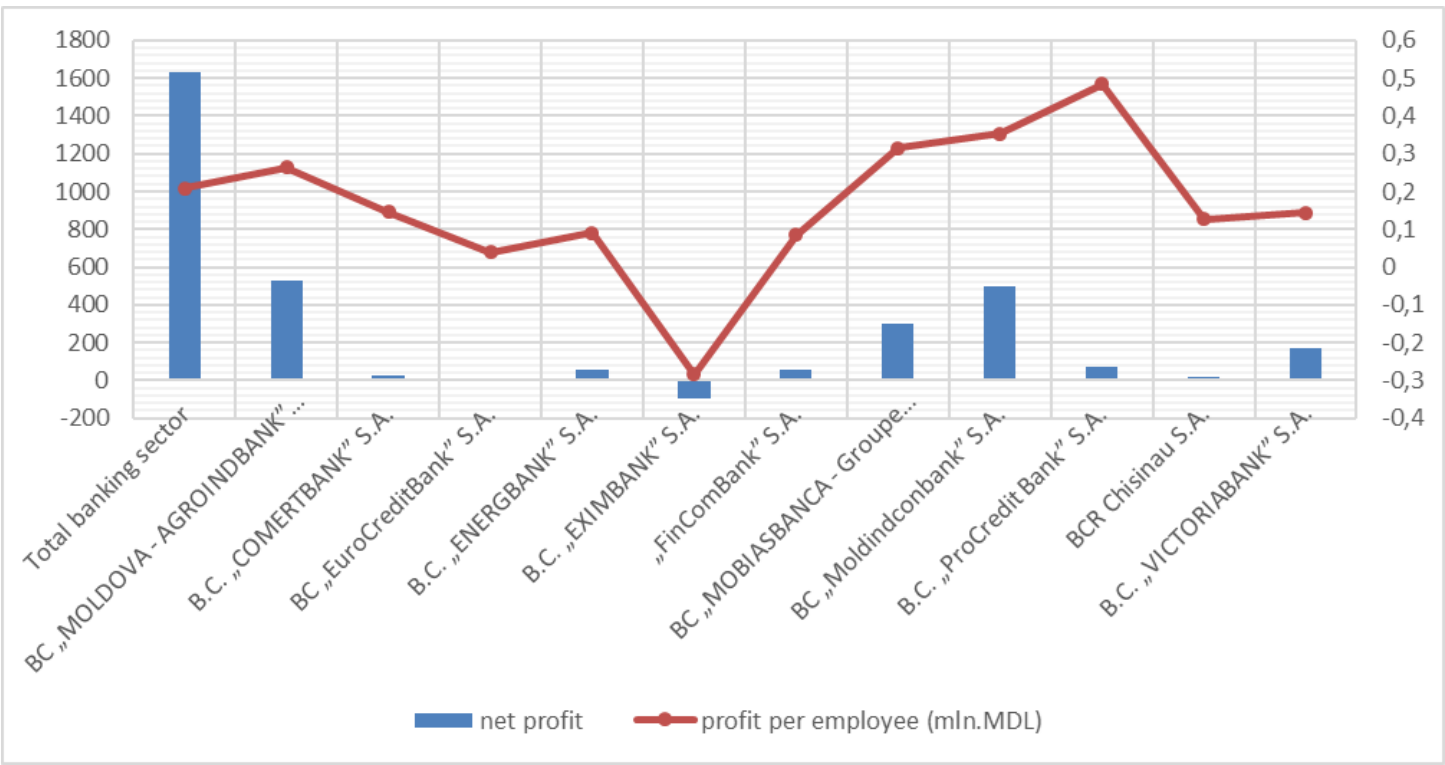

Fig. 2. Profit per employee in moldovan banking system, (mln.MDL) [16]

Analyzing the notion of efficiency it can be seen that it is dependent on some qualitative factors, which gives it a complex character. The study of bank efficiency mainly involves a causal analysis of the factors that determine the decisions in a related risk environment. Evaluating the factors that influence the effectiveness of the banking system is not an easy task, a large number of factors need to be considered. That is why different studies that have examined the magnitude of bank efficiency have tried to highlight the variables that influence this efficiency. 
In the present study, we intend to analyze in particular the effect of the banking staff management on bank efficiency, as it is mostly dependent on the way the bank employees work. Staff efficiency is significant and essential to any organization.

To analyze the banking staff efficiency, we have looked at some indicators: profit per employee, wages as $\%$ of total expenses, wages as $\%$ of total income.

This indicator indicates the amount of profit earned per employee of the bank. The higher the profit per employee, the greater the efficiency of the bank. From the above figure, we can see the interdependence between the bank's net profit and the profit on an employee. Small banks like B.C. "ProCredit Bank" S.A., B.C. "COMERTBANK" S.A. B.C. "ENERGBANK" S.A., in terms of staff management, are more efficient because profit per employee is higher compared to net profit.

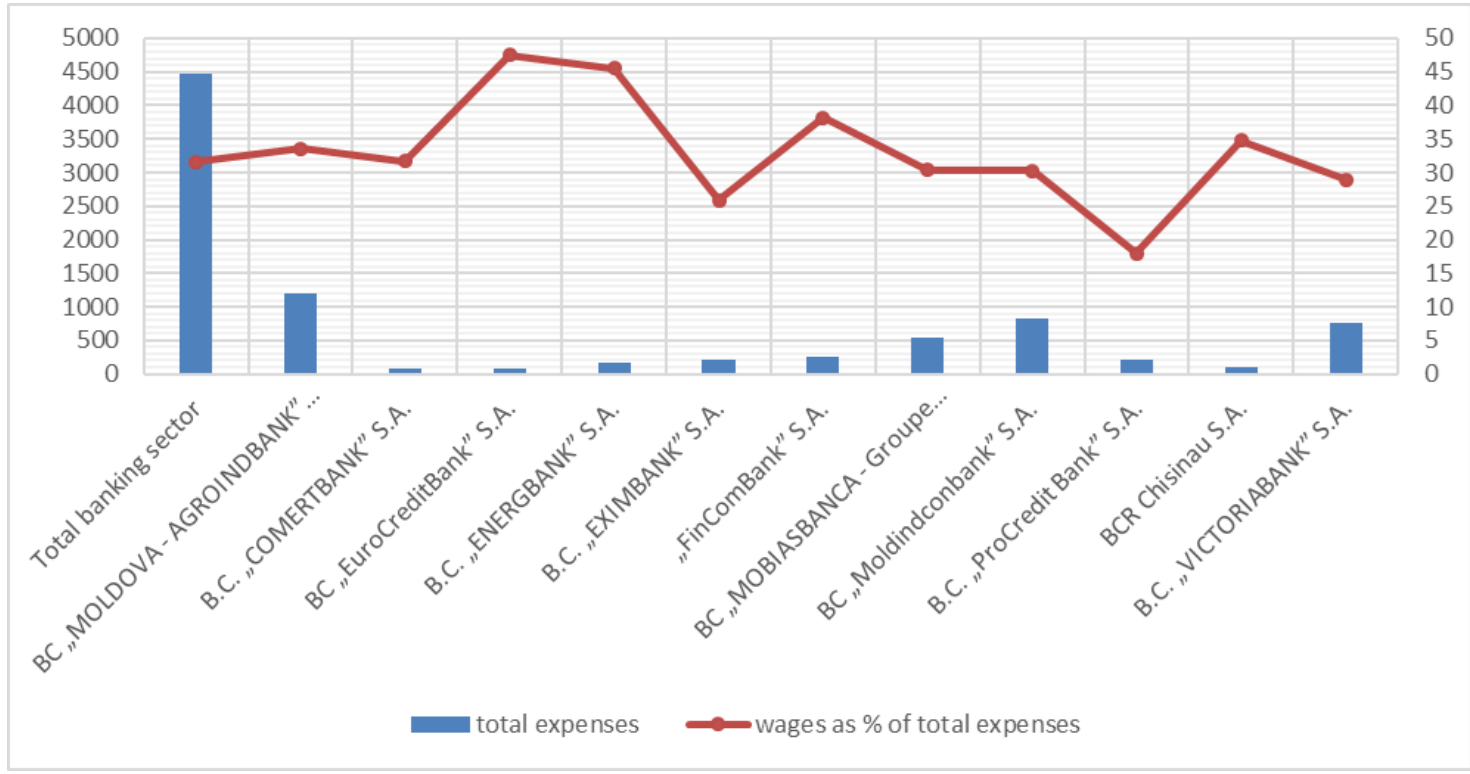

Fig. 3. Wages as \% of total expenses [16]

The share of wages in the bank's total expenditures is a parameter that indicates the good efficiency of the bank in the case of reducing personnel costs. From the above figure, we can see that "ProCredit Bank" S.A., has the best situation of this parameter, B.C. "EuroCreditBank" S.A. recorded the most unfavorable case.

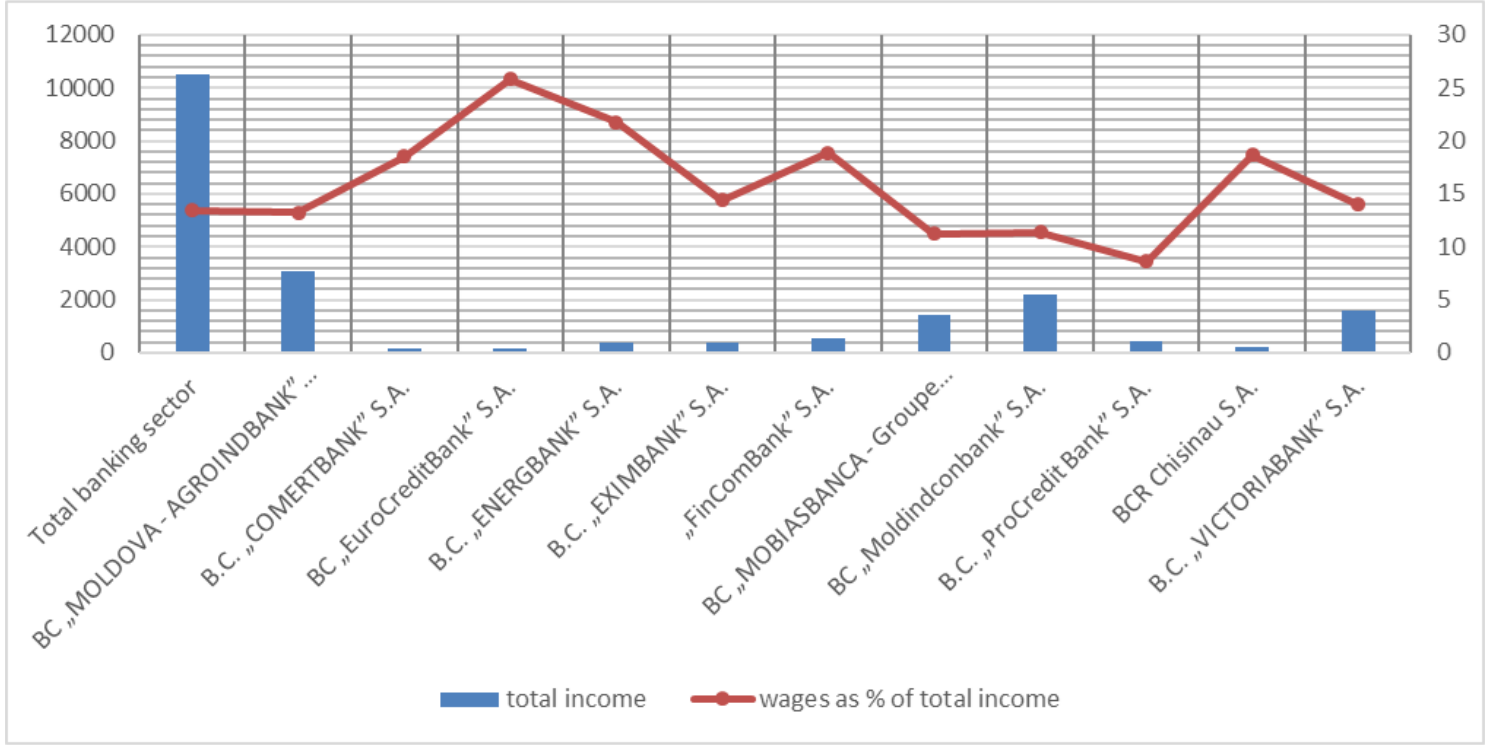

Fig. 4. Wages as \% of total income [16]

Another indicator that can be analyzed in the context of the efficiency of personnel management is the share of wages in the bank's total income. The efficiency of the bank will increase if this indicator is diminished. 
According to this indicator B.C. "ProCredit Bank" S.A., BC "MOBIASBANCA - Groupe Societe Generale" S.A. and BC "Moldindconbank" S.A. have the best situation.

Based on the analysis can be highlighted, the bank that best manages its banking staff, namely "ProCredit Bank" S.A., because its profitability indicators are higher than the average on the Moldovan banking system.

Conclusions. One of the main problems in the functioning of the banking system is the increase in its efficiency, determined by the level of achievement of its essential economic functions and the achievement of the objectives set by the society

The banking system is a crucial component of the national economy that should not only ensure its normal functioning but also create conditions for growth, optimization, and scientific and technological development.

Being a concept with a complex character, the efficiency of the banking system poses the issue of assessing the factors that influence it. Efficiency depends on many factors. The environment in which banks are located determines very much the managerial decisions, specialization, the bank's stability as a financial institution, its liquidity and its ability to cope with the intermediate functions.

One of the fundamental factors influencing the Moldovan banking system, analyzed in the present study, is the efficiency of the personnel management.

From the analysis, it can be noticed that there is a link between the banking efficiency and the efficiency of banking staff management. Banks with better indicators of bank management efficiency also have higher banking efficiency.

However, it is necessary to mention that the formation of an efficient bank management system also objectively requires an increase in employee motivation and professional training.

\section{REFERENCES}

1. O'Donnell, C.J. (2010). DPIN Version 3.0: A Program for Decomposing Productivity Index Numbers. Centre for Efficiency and Productivity Analysis Working Papers, University of Queensland. ISSN: 1932 - 4398

2. Sufian, F. (2009). The Impact of the Asian Financial Crisis on Bank Efficiency: The 1997 Experience of Malaysia and Thailand. Journal of International Development, 22, 866-889.

3. Hahn, F.R. (2007). Environmental Determinants of Banking Efficiency in Austria. Empirica, Vol. 34, 231-245

4. Hoffmann, P. S. (2011). Determinants of the Profitability of the US Banking Industry. International Journal of Business and Social Science, 2(22)

5. San, O. T., Heng, T. B. (2013). Factors affecting the profitability of Malaysian commercial banks. African Journal of Business Management, 7(8), 649-660

6. Maredza, A., Ikhide, S. (2013). Measuring the Impact of the Global Financial Crisis on Efficiency and Productivity of the Banking System in South Africa. Mediterranean Journal of Social Sciences, Vol 4., No 6., 553-568. ISSN: 2039-9340

7. Chortareas G.E., Garza, Garcia J.G., Girardone C. (2011). Banking Sector Performance in Latin America: Market Power versus Efficiency. Review of Development Economics, Vol. 15, N. 2, 307-325

8. Salem,M.S., Rahman, N.A. (2016). The effect of bank-specific factors and unstable macroeconomic environment on bank efficiency: evidence from FCC. International Journal of Advanced and Applied Sciences, 3(9), 97-102

9. Kauko, K. (2007). Managers and efficiency in banking. Bank of Finland Research Discussion Papers, 11

10. Yaseen, A. (2015). Performance Management Practices And Its Impact On Banks' Performance In Pakistan. International Journal of Human Resource Studies, Vol. 5, No. 4, 110-127. ISSN: 2162-3058

11. Bowra, Z., Niazi, K. (2012). Impact of human resource practices on employee perceived performance in banking sector of Pakistan. African Journal of Business Management Vol. 6(1), pp. 323-332. ISSN 1993-8233

12. Popa, M. Analiza factorială. [online]. < http:/ st_io_10_an_factoriala\%20(2).pdf/ >

13. Athanasoglou, P. P., Brissimis, S. N., Delis, M. D. (2008). Bank-specific, industry-specific and macroeconomic determinants of bank profitability. In: Journal of International Financial Markets, Institutions and Money, 18(2), 121-136. ISSN: 1042-4431

14. Dietrich, A., Wanzenried, G. (2014). The determinants of commercial banking profitability in low-, middle-, and high-income countries. In:Quarterly Review of Economics and Finance, 54(3), 337-354. ISSN: 1062-9769

15. Demirgüç-Kunt, A., Huizinga, H. (1999). Determinants of commercial bank interest margins and profitability: Some international evidence. In: The World Bank Economic Review, 13(2), 1-38. ISSN: 0258-6770

16. Informație privind activitatea economico-financiară a băncilor din RM. [online]. < http://www.bnm.md/bdi/pages/reports/drsb/DRSB1.xhtml?id=0\&lang=ro> Contul de profit sau pierdere [online]. < http://www.bnm.md/bdi/pages/reports/drsb/DRSB6.xhtml> 